\title{
THE INTERGRATION CONCEPT OF NAQLI AND AQLI KNOWLEDGE: STUDY ON STUDENTS' PERCEPTION
}

\author{
Mohamed Akhiruddin Ibrahim ${ }^{1 *}$, Azniwati Abdul Aziz², Wan Amir Nudin Wan Ishak ${ }^{2}$, \\ Sanusi Shariff ${ }^{2}$, Rasmina Hasbullah ${ }^{2}$, Irwan Mohd Subri ${ }^{3}$ \\ ${ }^{1}$ Dr, Faculty of Quranic and Sunnah Studies, Universiti Sains Islam Malaysia, MALAYSIA, \\ akhiruddin@usim.edu.my \\ ${ }^{2}$ Tamhidi Centre, Universiti Sains Islam Malaysia, MALAYSIA \\ ${ }^{3}$ Faculty of Shariah and Law, Universiti Sains Islam Malaysia, MALAYSIA \\ ${ }^{*}$ Corresponding author
}

\begin{abstract}
Integrating Naqli and Aqli knowledge is the vision of Universiti Sains Islam Malaysia (USIM), Malaysia, to transform and create value for country, ummah and humanity. This concept becomes fundamental in university's curriculum for students that pursuing their studies in a various disciplines of knowledge. It is in line with the Malaysian Education Development Plan, which aims to create young generation who are knowledgeable, have an ability to think critically and creatively, have a strong leadership skills and ability to communicate effectively at the global stage. The study intends to examine the perception of students that adhere to curriculum that based on the integration of Naqli and Aqli knowledge, especially in USIM. Data was obtained through distributed questionnaire form to students about their perception towards curriculum of integrating Naqli and Aqli knowledge. 114 students from Tamhidi were selected as respondents in this study case. The study found that majority of respondents has a basic knowledge about the integration of knowledge since their secondary school. This is because mostly they came from religious secondary school from either federal, state or private school. The study also found that the subject-based Islamic Education plays an important role as it gives an overview of the integration of Naqli and Aqli. Majority of respondents were able to differentiate between the two knowledge, however this study shows that it was difficult for them to present some examples that explain the integration of both knowledge. In addition, this study revealed that majority of respondents get clear information regarding to the integration of both knowledge in the courses offered by the department. As a student of USIM, the majority of respondents are aware that the institution is a public university that implements integration of Naqli and Aqli knowledge in offered curriculum.
\end{abstract}

Keywords: Perception, Naqli and Aqli, Quran, university

\section{INTRODUCTION}

Islam devotes great importance of knowledge and education. Knowledge is the awareness of a thing with reference to its reality (Raghib Asfahani, 1992) while education is something progressively instilled into man 
(Al-Attas, 1980). When the first of the Qur'an revealed, the first word of the first verse was 'lqra' that means, read. Allah said, which means: Read! In the Name of your Lord Who created. He has created man from a clot. Read! And your Lord is the Most Generous. Who has taught by the pen. He has taught man that which he knew not. (Quran, 96: 1-5)

These five verses described about how Gabriel appeared to Prophet Muhammad P.B.U.H. when he was meditated in a cave on a mountain called Hira' in Mecca. This event has changed the history of mankind forever in terms of the fact, the significance and the consequences (Syed Qutb, 1992). This is because the meaning behind this event is to worship Allah as the only God and to know Allah is by being educated.

According to Al-Qadri (2007), man knew nothing and lives in ignorance before the revelation but now he was blessed with knowledge and brought to light. It was light of awareness that was bestowed upon him. Allah connected man to the system of education and exploration of knowledge revealed in these five verses and enlighten human mind with numerous light of understandings.

Knowledge can be divided into two types, one is the knowledge of religion or the revelational sciences which is called naqli knowledge, and the second one is the knowledge required by community or the rational sciences which is called aqli. It is a parent's obligation to ensure their children obtained both type of knowledge (Mohd Hamid \& Khaulah, 1994), for example Tawheed (believing in one God) is to be taught first when it comes to religious knowledge, followed by Salah (the act of prayer) and recite the Holy Book (Quran). On the other hand, the existence of doctor, engineer, lawyer, etc. are required for the betterment of society, nevertheless this second type of knowledge should not take people far from God but to take them closer to.

That is why USIM embraces both of holistic approach which unites Naqli and Aqli towards the delivery of knowledge not only in the courses offered, but is also widely practised throughout the university including administration and management levels. This approach has been trained to students of this university since their Tamhidi (foundation) level and most of them came from similar background which is religious secondary school.

USIM's Tamhidi programme for SPM graduate which aims to prepare candidates for the First Degree level. Tamhidi is derives from one of Arabic word which means 'preparation' such as the term 'Matriculation in the Ministry of Education and International Islamic Universiti Malaysia, 'Foundation' in Universiti Malaya, 'Foundation Year' in University Teknologi Malaysia or similar to pre-university programme (STPM, HSC or A' Level). Thus, Tamhidi programme is equivalent to 'foundation' programme run by universities that have been listed (Ibrahim, 2016).

Therefore, the fact is basically they have been received Islamic education through formal education even since primary school and followed by secondary school such as Islamic Education subject offered during primary school and lower secondary school, and for upper secondary school there are Quran and Sunnah Education, Syariah Islamiyah Education and Tasawwur subject offered. So it is almost impossible for them to say that they have no idea what is Naqli and Aqli knowledge since they had learned about it for a very long time. For this reason, they should be able to differentiate between both knowledge and present some example if they had received clear explanation about the knowledge since primary school.

So this study is prepared to know to which extent is their perception about Naqli and Aqli knowledge during their Tamhidi level and their thought about USIM as a public university that implement Naqli and Aqli towards the delivery of knowledge to respond to USIM strategic planning 2016-2025 (PSUSIM16:25) which aims to become a reference centre for the Integration of Naqli and Aqli knowledge at regional level by 2016 and international level by 2025 (Ibrahim, Shaker, Sulaiman, Aziz, Ghaffar \& Yusup, 2016).

\section{RESEARCH METHODOLOGY}

Research methodology is the most important thing in case study. It is a systematic process in defining the objectives, managing the data, and communicating the findings occur within established frameworks and in accordance with existing guidelines (Williams, 2007). Empirically, this study employed quantitative research which typically begins from collecting data using survey research.

According to Kerlinger (1973), survey research is a study on large and small populations by selecting samples chosen from the desired population and to discover relative incidence, distribution and interrelations. In this method, a researcher poses a series of questions to the respondents, summarises their responses in percentage, frequency distribution and some other statistical approach.

In this research, a questionnaire form has been used to collect data. Cohen, Manoin, \& Marrison, (2000) claimed that the questionnaire is widely used and useful instrument for collecting survey information, 
providing structured, often numerical data, being able to be administrated without the presence of the researcher. Also comparatively, this method involve low cost and straightforward to analyse.

In general, each set of questionnaire is divided into two sections, Section A: Background information on respondents, Section B: Require respondents to answer 6 questions related to Naqli and Aqli knowledge based on Five Likert Scale which is Strongly Disagree (1), Disgree (2), Not Sure (3), Agree (4) and Strongly Agree (5). This attitudinal scales was created by Likert because of the difficulty of measuring character and personality traits then the data analysed based on the composite score (Harry N. B. \& Deborah A. B., 2012). Hence, this B section intend to observe respondents' perception towards Naqli and Aqli knowledge which contains 6 questions.

The question asked was related to their acquisition about Naqli and Aqli knowledge during their secondary school, the role of Islamic Education subject during secondary school and its' benefit in giving overview about Naqli and Aqli knowledge, an ability to differentiate between Naqli and Aqli knowledge, the difficulties in giving example regarding to Naqli and Aqli knowledge, the acquisition of clear explanation about Naqli and Aqli knowledge in all courses during their Tamhidi level and their consent about USIM as a public university that implement Naqli and Aqli knowledge. After the data collected, the results will be analysed using SPSS software and descriptive research findings will be conducted.

A total of 114 students from Tamhidi Syariah and Law were chosen consist of 41 males and 73 females which bring the percentage of male respondents $36 \%$ while female respondents $64 \%$. This percentage shows that female is a dominant sample in this study. As a matter of fact, secondary school background may influence their perception regarding to their Naqli and Aqli knowledge. The acceptance of academic subject followed by Islamic Education in formal education institution which is school, could give the respondents some overview about both of the knowledge. This is because mostly they came from almost similar religious secondary school from either federal, state or private school but majority of them came from state government secondary school. It is proved by majority of them claimed that they have high interest in learning more thoroughly about Naqli and Aqli knowledge since they have learned the basic one from secondary school.

\section{RESEARCH FINDINGS AND DISCUSSIONS}

Various types of secondary school in Malaysia might influenced respondents' acquisition of Naqli and Aqli knowledge. As Manuty (1984) indicated, the establishment of religious school related with process of Islamic education and the spread of Islam in Malaysia. Islamic education in Malaysia is going through a long period of time since the arrival of Islam to Malay Land and it continues until today.

Religious school in Malaysia not only deliver basic knowledge but it also become main Islamic education's institution because the knowledge of Islam and the nurturing of Islamic value has been implemented in order to create personality of Muslim children (Masitah \& Aizan, 2015).

As mentioned before, during Tamhidi level, students are making preparation to elevate themselves to another level which is Bachelor's Degree and generally they came from almost similar secondary school background which is religious secondary school. So this research has an expectation that most of them have about same opinion regarding to Naqli and Aqli knowledge. It has been proven by results from the respondents that majority of them had a thought that the knowledge of Naqli and Aqli gained since their secondary school. Hence, the first item (C1) asked is about their knowledge of Naqli and Aqli knowledge gained during secondary school.

\begin{tabular}{|c|c|c|c|c|c|}
\hline \multicolumn{2}{|c|}{ C1 } & Frequency & Percent & Valid Percent & $\begin{array}{c}\text { Cumulative } \\
\text { Percent }\end{array}$ \\
\hline \multirow{4}{*}{ Disagree } & 5 & 4.4 & 4.4 & 4.4 \\
\cline { 2 - 6 } & Not Sure & 22 & 19.3 & 19.3 & 23.7 \\
\cline { 2 - 6 } & Agree & 60 & 52.6 & 52.6 & 76.3 \\
\cline { 2 - 6 } & Strongly Agree & 27 & 23.7 & 23.7 & 100.0 \\
\cline { 2 - 6 } & Total & 114 & 100.0 & 100.0 & \\
\hline
\end{tabular}

Table 1: The percentage of respondents who are agree that the knowledge of Naqli and Aqli gained during their secondary school. 
Table 1 clearly shows that more than half respondents which is $52.60 \%$ out of them are "agree" and $4.40 \%$ are "disagree" with this statement. Meaning that minority said they were not obtained knowledge of Naqli and Aqli during their secondary school. While $23.70 \%$ are "strongly agree" and $19.30 \%$ are "not sure" whether they had obtained Naqli and Aqli knowledge from secondary school or not. Those who claimed that they were not agree and not sure about acquisition of Naqli and Aqli knowledge during secondary school is probably because they were confused about the meaning of Naqli and Aqli knowledge in the first place because that terms are available in the content of subject such as Islamic Education subject.

Therefore, Naqli and Aqli knowledge has really strong connection with Islamic Education subject since it describes about religious and rational sciences. According to Mohamad, Suradin \& Khamisan (2004), Islamic Education subject is a subject offered in primary and secondary school which aimed to create pious, educated and ethical individual in this world and hereafter. Therefore, this subject must be introduced and taught as a way of life, not just for the sake of deliver the information and knowledge alone but it must be practised by every individual Muslim since childhood. Solehah et.al (2008) also claimed the ultimate goal of this this Islamic education is related to character building which required beliefs and values as key elements in the implementation of integrated Islamic curriculum. Hence, Islamic Education subject learned in schools affect students' perceptions about Naqli and Aqli knowledge especially through text book used in class as a teaching and learning process which is in the form of text, illustrations, activities, descriptions and photos (Mahanom, 1998).

The effectiveness of this subject can be seen through three aspects. The first one is through implementations, the second one is through achievement in examination and the third one is through appreciation and practice (Suzalie, 2003). So as long as they practice what they have learned through the subject since secondary school, it should be no problem to understand Naqli and Aqli knowledge through all courses in Tamhidi. This second item (C2) is about relation between Islamic Education subject learned during secondary school and Naqli and Aqli knowledge.

\section{C2 The percentage of respondents who are agree that Islamic Education subject give clear explanation regarding Naqli and Aqli knowledge}

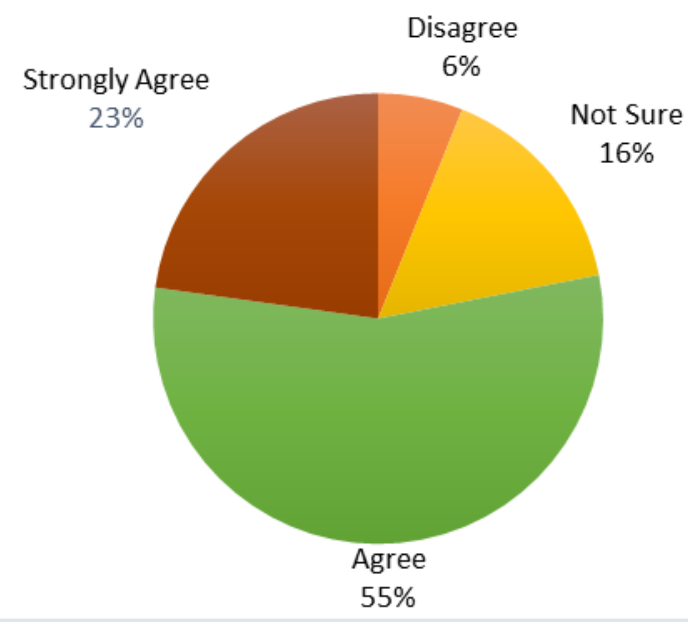

Disagree

Not Sure

- Agree

- Strongly Agree

Pie Chart 1: The percentage of respondents who are agree that Islamic Education subject give clear explanation regarding Naqli and Aqli knowledge.

The analysis yielded that more than half $(55 \%)$ respondents indicated that they were "agree" that Islamic Education subject give clear explanation regarding Naqli and Aqli knowledge while a total of $6 \%$ were "disagree" with that statement. The big difference seen between those who are agree and not agree that Islamic Education subject give clear explanation regarding Naqli and Aqli knowledge shows the importance of Islamic Education subject in producing human that devoted to God and creating young generation based on Al-Quran and As-Sunnah. None of them chose strongly not agree shows that they might have even slight idea about the relationship between Naqli knowledge and Islamic Education subject.

Thus, they must know the difference between both of the knowledge. Basically, Islamic education consist of both religious science which derived from divine revelation and acquired science which gained through human intellectual capabilities both type of knowledge should be integrated with the principle of Tawheed or Divine Unity as mentioned before (Solehah \& Rahimah, 2008). 
Integration refers to the process that combines or collects things. Essentially, it is a process of uniting something to achieve particular aims in producing new things. In context of knowledge, integration means the combination of two disciplines of knowledge which create new knowledge such as the concept of integrating Naqli and Aqli knowledge in USIM's vision (Ibrahim, Yusoff, Aziz \& Nor, 2015). When it comes to combination of two knowledges, both of them supposed to bring two different meanings.

For example, studies in Geography limited to only real world. However, study of the supernatural in nature such as the transition of day and night, the creation of moon and sun and many more, refers to understanding the nature created by Allah. Meanwhile western view emphasise on the phenomenon of things or events. It is different from Islam view because it is not only study about the phenomenon of creation but also the wisdom behind it. Therefore, it is clear that both knowledge are different in certain way but both of them have strong connection. It was proved by the results collected from respondents about their capability to distinguish between Naqli and Aqli knowledge, which is the third item (C3) in this study.

\begin{tabular}{|c|c|c|c|c|c|}
\hline \multicolumn{2}{|c|}{ C3 } & Frequency & Percent & Valid Percent & $\begin{array}{c}\text { Cumulative } \\
\text { Percent }\end{array}$ \\
\hline \multirow{2}{*}{ Not Sure } & 25 & 21.9 & 21.9 & 21.9 \\
\cline { 2 - 6 } & Agree & 65 & 57.0 & 57.0 & 78.9 \\
\cline { 2 - 6 } & Strongly Agree & 24 & 21.1 & 21.1 & 100.0 \\
\cline { 2 - 6 } & Total & 114 & 100.0 & 100.0 & \\
\hline
\end{tabular}

Table 2: The percentage of respondents who are agree with their abilities to differentiate between Naqli and Aqli knowledge.

Table 2 shows the percentage of respondents who are agree with their abilities to differentiate between Naqli and Aqli knowledge. Fortunately, the results can be seen as positive result when neither of them chose "strongly disagree" nor "disagree".

It was obvious that most of them know that both of the knowledge is different to each other since majority of them chose "agree" and "strongly agree". More than half of respondents which is $57.0 \%$ "agree" with their abilities to differentiate between Naqli and Aqli knowledge and $21.10 \%$ from them claimed that they are "strongly agree" with that statement. This is because they are confident that they have obtained Naqli and Aqli knowledge since primary school, which is formal education institution. While those who are "not sure" is $21.90 \%$. There is a possibilities that they are confuse regarding both knowledge because of the strong connection with each other.

Naqli and Aqli knowledge is two different type of knowledge and each of the respondent should be able to differentiate between both knowledge since it is like a fertilizer for USIM, as it will determine the ecosystem in this university (Zainuddin, Idrus \& Jamal, 2016). They describe that USIM is unique because it is the only university that implement the concept of Naqli and Aqli into the curriculum and governance. The aim of the university for its' graduate is to become a professional in their respective disciplines effectively and at the same time they are capable to contribute to the development of Islam. That is why the thorough understanding about Naqli and Aqli are important to realize USIM's goal.

If the respondents can differentiate between both of the knowledge completely, supposedly they have no problem to present clear examples that explain the integration of Naqli and Aqli knowledge because they know the content and they can relate all rational sciences with Islamic elements as stated in Quran and Sunnah. These examples become an evidence to prove that the respondents seriously understand the meaning of Naqli and Aqli. Deep understanding about the integration both of the knowledge in education can bring positive effect in self-development, ummah (community) and country.

The reason is, the final aim for this integrated knowledges in education is producing human with high intellectual, multi-skill, proactive and positive towards knowledge (Zetty \& Ab.Halim, 2015). This final aim will ring human close to the truth, especially about the meaning of life and its' purpose which at the end they will achieve self-actualization (Rohana, 2010).

Hence, the fourth item (C4) from this research found out the level of difficultness faced by respondents in presenting some clear examples that explain the integration of Naqli and Aqli knowledge. The results show that the respondents were quite hesitating to answer this question because all five scales were selected randomly. 
It was proved by $42.1 \%$ of respondents are "not sure" about the difficulty to present some clear examples that explain the integration of Naqli and Aqli knowledge which brings the majority. Only 1,8\% of respondents confident with their knowledge regarding to Naqli and Aqli while 5.3\% "strongly agree" about the toughness of presenting example from Naqli and Aqli knowledge. This is probably because some of them still unable to understand Naqli and Aqli concept thoroughly. Therefore, examples of Naqli and Aqli knowledge should be clarified with more detail in each courses, so that the respondent can distinguish the two branches of knowledge.

Logically they should be able to present some examples regarding Naqli and Aqli knowledge because it was applied in all of their courses during Tamhidi level even in social and physical sciences subject. Even though it was the knowledge create by human rational, it will relate to the supernatural in nature that created by God at the end of the lesson.

Therefore, the fifth item (C5) studied trough out this research is whether they were getting clear information about Naqli and Aqli knowledge through all courses in Tamhidi or not.

Until now there are five programmes available in Tamhidi level which are Tamhidi of Medicine, Tamhidi of Dentistry, Tamhidi of Science and Technology, Tamhidi of Syariah and Law and Tamhidi of Accounting and Muamalat (Ibrahim, 2016). Based on list of courses for Tamhidi students, Islamic element subject has been inserted in each Tamhidi programmes such as al-Quran and Hadis in Sciences (al-Quran wa al-Hadis fi alUlum) (http://tamhidi.usim.edu.my/en/program-akademik/senarai-kursus-dan-jam-kredit). Clear and thorough explanation could answer their inquiries about Naqli and Aqli knowledge. Generally, not just subjects that have been seen clearly as Islamic subject considered as Naqli knowledge. Even the core subject itself is integrated by Naqli and Aqli knowledge for example the dimension of science and technology in Quran.

Thus, as pointed out by Khairi (2010), Quran's point of view about science and technology can be discovered by how Quran's view about knowledge, which known as the highest position as well as faith (iman). He also indicated that to understand sunnatullah in this universe, human have been provided with two potentials, the first one is from inner self of human which also known as fitrah (natural) potential and the second one is from outer self of human which is nature resource potential. Only those who are educated and intelligent can relate and think about the power of Allah through His signs such as knowledge of nature like mathematics, physics, chemistry, biology, geology and many more are instruments to understand natural phenomenon precisely.

\section{The percentage of respondents who are agree for getting clear information about Naqli and Aqli knowledge through all courses in Tamhidi}

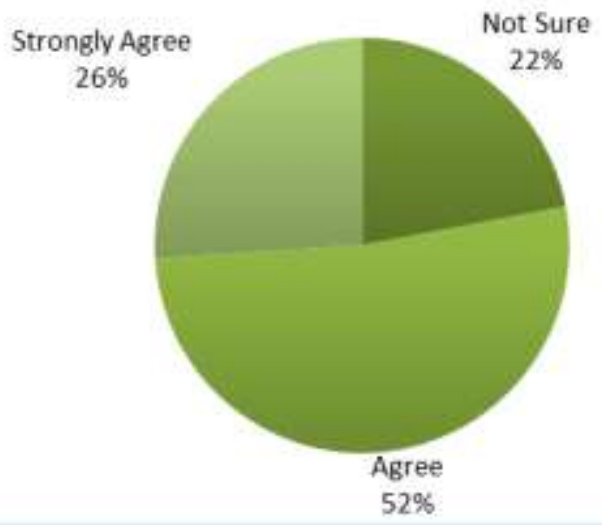

Not Sure

ш Agree

w Strongly Agree

Pie Chart 2: The percentage of respondent who are agree for getting clear information about Naqli and Aqli knowledge through all courses in Tamhidi.

Therefore, the analysis yielded positive result regarding this question since most of them chose "strongly agree" and "agree". With reference to Pie Chart 2, majority (52\%) of the respondent "agree" in getting clear information about Naqli and Aqli knowledge through all courses in Tamhidi while $26 \%$ of the respondents "strongly agree". This result show that most of them understand what they have learned in class and capable to relate the lesson with the integration of Naqli and Aqli knowledge.

But $21.90 \%$ of the respondents chose "not sure" with that statement. Those who are select this answer probably consist of those who cannot differentiate between Naqli and Aqli because it is impossible to get 
clear information regarding to Naqli and Aqli knowledge through all courses in Tamhidi if they are unable to differentiate between them because it is related with each other. Furthermore, neither of them chose "strongly disagree" nor "disagree", shows that most of them thought that they had got benefit through learning process about Naqli and Aqli knowledge that they obtained during Tamhidi level.

Lastly (C6), the analysis revealed about respondents' perception toward USIM as a public university that implement the integration of Naqli and Aqli knowledge. Relation between science and Islam known as integration relation. This integration can be divided into two types, first is natural theology which see all science findings as the way to become closer to God. The other type is theology of nature which described that discovery of God should be upgraded continuously in line with development of knowledge (Barbour, 2005). USIM is the first public university in Malaysia that provides science and Islamic studies at the same time for example for undergraduate studies there is Bachelor of Quranic Studies with Multimedia programme and Bachelor of Sunnah Studies with Information Management programme under Faculty of Quran Sunnah Studies (Ibrahim, Yusoff, Aziz, \& Nor, 2015)

Meanwhile, during Tamhidi level, USIM only focus on five programmes because the university want to focus more to the quality of the students instead of the quantity because their aims is not only to produce students that capable to compete in faculty level but to develop human capital which can contribute to community and Islam through professional carrier (Aziz, Hasbullah, Ishak, Shariff, Ibrahim, Subri \& Suhaimi, 2016)

Therefore, relationship between science and Islam is extremely important and it is proven by 67 out of 114 respondents chose "strongly agree" that USIM is a public university that implement the integration of Naqli and Aqli knowledge which brings a total of majority, and 40 of them chose "agree" with that statement. This outcome shows positive results among respondents since most of them put their trust in USIM in implementing the integration of Naqli and Aqli knowledge through education in all courses offered.

While only 7 of the respondents "not sure" whether USIM is a public university that implement the integration of Naqli and Aqli knowledge or not. This is probably because they are not thoroughly understand the meaning of Naqli and Aqli knowledge and unable relate the knowledge with what they have learned during Tamhidi level. The fact is the integration of Naqli and Aqli can be seen in USIM make the university remarkable compared to other university in terms of creating better ummah not just in this world but also in hereafter. It is good that neither of them chose "disagree" nor "strongly disagree" in this case because it has proved that most of them have good perception toward USIM's vision in integrating Naqli and Aqli knowledge.

\section{Crosstabs}

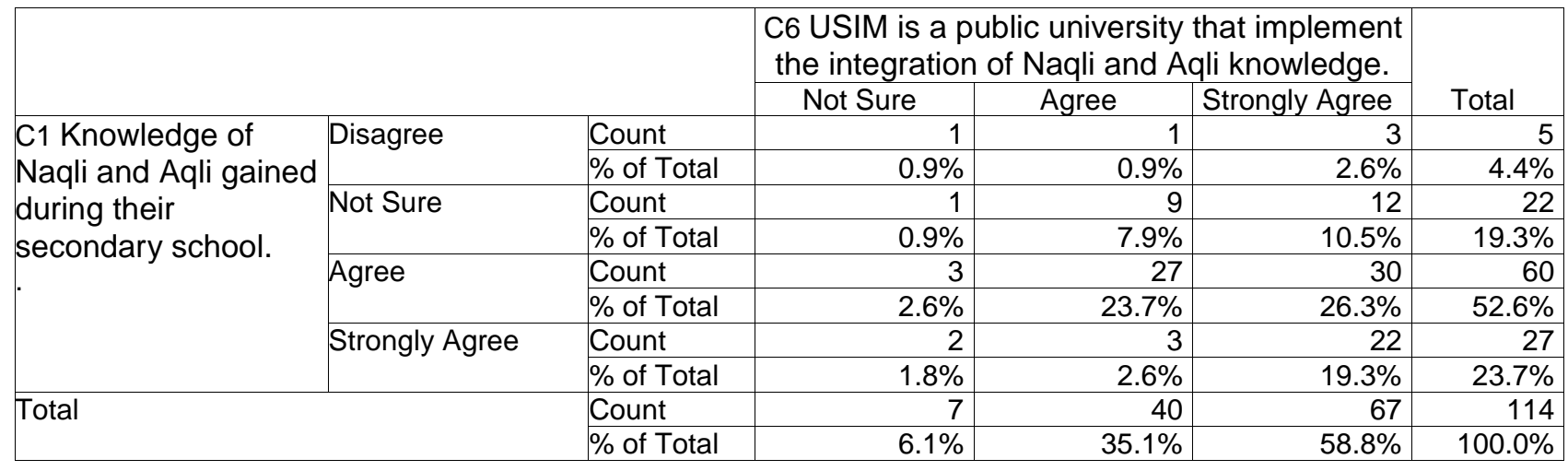

Table 3: Crosstabs Item C1 and C6

Table 3 demonstrates a crosstab between Item C1 (Knowledge of Naqli and Aqli gained during their secondary school) and Item C6 (USIM is a public university that implement the integration of Naqli and Aqli knowledge). There are 60 respondents who are "agree" with Item C1 and 67 claimed they are "strongly agree" with Item C6. Research concluded that the students could understand the question given properly and give feedback seriously. Yet no doubt that the increasing percentage also shows that some of the respondents have fixed perception about this issue. This is because they have obtained Naqli and Aqli knowledge since their secondary school. Item C1 and C6 should have equivalent result because majority of the respondent had received academic education together with Islamic education become continuity of knowledge in USIM. It can be concluded that USIM is a public university that implement the integration of Naqli and Aqli and not contradict with their knowledge about Fiqh (Islamic Jurisprudence) in secondary school and USIM. 


\section{CONCLUSION}

Islam is not just about salah (praying), dhikr (chanting), fasting and so on but it is comprehensive in all aspects in this life. That is why the concept of integrating Naqli and Aqli concept exist in education system that can develop better ummah by focusing on Islamic values and morals. Integrated Islamic curriculum aims to produce an integrated Islamic personality in accordance with Allah's will. That is why USIM uphold a balanced approach between both of the knowledge.

The findings reached the conclusion that background information of respondents affected their perception about the integration concept of Naqli and Aqli knowledge since majority of them claimed that they have obtained both of the knowledge from secondary school. Meanwhile there was still some of them hesitate about the acquisition of Naqli and Aqli knowledge during secondary school. These two knowledge have a strong connection with Islamic education subject that they had learned during secondary school. This subject give a big impact to respondents in order to understand and relate Naqli and Aqli knowledge in practice. So they should have known about the concept as long as they understand it thoroughly and practise it in everyday life since it is long learning process.

The results also indicated positive results when majority of them capable to differentiate between Naqli and Aqli knowledge. Despite the encouraging findings, this study found that they have faced the difficulty in presenting some clear examples that explain the integration of Naqli and Aqli. This result was contradict with positive results at the beginning of the questionnaire probably because they could not think right away about the example that explain both of the knowledge. Furthermore, the findings show that more than half of the respondents get clear information about Naqli and Aqli knowledge through all courses in Tamhidi and consent to the fact that USIM is a public university that implement the integration of Naqli and Aqli knowledge. But overall, their perception towards this concept is at a satisfactory level.

To make all Tamhidi students understand about this concept is not an easy task. Persistent efforts in a very comprehensive, critical and creative manner are needed in order to achieve this vision because they are newcomer in pre-university life and still need some time to adapt to the new environment and the new education system which is different from teaching and learning process at school. It becomes one of great challenge for them in order to enter the real of university life, depends on their interest and willingness to understand the concept.

Given the findings and conclusions, the study suggested that the first step to take is to re-discover students' understanding towards religion for example some religious terminology such as jihad, ilm, ihsan, iman and taqwa should be interpreted in a wider context than just religious terminology and relate it with all courses in Tamhidi. Furthermore, teaching and learning process in class need an improvement in-line with the development of science and technology.

It is hoped that this study can discover perception of Tamhidi students toward the integration concept of Naqli and Aqli knowledge in USIM, so that the university can provide more clear picture of the concept make sure that all students understand the concept to produce Muslim individual with good quality. In a nutshell, a way to improve the level of effectiveness in teaching and learning process should be devised urgently to uphold USIM's basic principle of both knowledge and promote Islamic solidarity for the ummah.

\section{ACKNOWLEDGEMENTS}

The researchers would like to acknowledge Research Management Centre, Universiti Sains Islam Malaysia (USIM) for the financial support as this research was a part of its Grant (PPP/USG-0115/FPQS/30/11415) and (PPP-TAMHIDI-17115-00).

\section{REFERENCE LIST}

The Holy Quran

Al-Attas, S.M.N. (1980). The Concept of Education in Islam: A Framework for an Islamic Philosophy of Education. Kuala Lumpur: Muslim Youth Movement of Malaysia (ABIM).

Al-Qadri, Muhammad Tahir, (2007). Islamic concept of Knowledge. Mainhaj-ul-Quran Publication. Lahore, Pakistan.

Aziz, A.A., Hasbullah, R., Ishak, W.A.W, Shariff, S., Ibrahim, M.A, Subri, I.M \& Suhaimi, F.F. (2016). Proceeding of Seminar Serantau Peradaban dan Pemikiran islam (ReCIT 2016) \& Eksplorasi Da'i 
Merentasi Benua, 5- 9 November 2106, Perth, Australia.

Barbour, lan G. (2005). Menemukan Tuhan Dalam Sains Kontemporer dan Agama. Bandung: Mizan.

Cohen, Manoin, \& Marrison, (2000). Research Methods in Education (5 ${ }^{\text {th }}$ edition). London: RoutledgeFalmer.

Harry, N. B. \& Deborah, N. B. (2012). Analysing Likert Data. West Virginia: West Virginia University Morgantown, Journal of Extension, 50(2), 1.

Ibrahim, M.A., Yusoff, A.M., Aziz, A.A., \& Nor, A.M. (2015). Integration Of Naqli And Aqli Knowledge In Education Curriculum : Experience Of Faculty Of Quranic And Sunah Studies, Universiti Sains Islam Malaysia. Proceeding of INTCESS 2015 2nd International Conference on Advances in Education and Social Sciences 2-4 February 2015, Istanbul, Turkey.

Ibrahim, M.A (2016). The Integration of Naqli Knowledge Of Science Courses In Institutions Of Higher Learning Foundation Centres: Study On Tamhidi Centre, Universiti Sains Islam Malaysia. Proceeding of ADVED 2016 2nd International Conference on Advances in Education and Social Sciences 10-12 October 2016- Istanbul, Turkey.

Ibrahim, M.A., Shaker, M.H, Sulaiman, S., Aziz, A.A, Ghaffar, N.S \& Yusup, M.H. (2016). THE Integration Of Naqli And Aqli Knowledge In Curriculum At Universiti Sains Islam Malaysia: The Study On Student's Internship Organizations In Kelantan, Malaysia. Proceeding of SOCIOINT 2016 3rd linternatiional Conference On Educatiion,, Sociial Sciiences And Humanities, 23 ${ }^{\text {rd }}$ - 25th May 2016, Istanbul, Turkey.

Kerlinger, F. (1973). The Structure of Scientific Revolution. Chicago: University of Chicago Press.

Khairi, J. (2010). Sains dan Teknologi dalam Al-Quran dan Implikasinya dalam Pembelajaran. Fakultas Tarbiyah IAIN Raden Intan Lampung: Ta'dib, Vol. XV No. 01, Edisi Juni 2010, 124.

Mahanom M.S. (1998). Evaluation of Malaysian Primary Science Text Books. Tesis M.Ed. University of Warwick, United Kingdom.

Masitah R \& Aizan A (2015). Sejarah (tipologi) Penginstitusian Sekolah Agama di Malaysia: Satu Analisis Perbandingan di YIK dan JAIS. Journal al-Muqaddimah, Department of Islamic History and Civilization.

Manuty, M.N. (1984). Perkembangan Pendidikan di Malaysia: Beberapa Analisa KritisTerhadap PemikiranPemikiran Asas dalam Perspektif Sejarah. Jurnal Pendidikan Islam 2, 46.

Mohamad, B., Suradin, A. \& Khamisan, Z.H. (2008). Persidangan Pembangunan Pelajar Peringkat Kebangsaan, Universiti Teknologi Malaysia.

Mohd Hamid, N., \& Khaulah, A. Q.D (1994). Tarbiyatul al-Atfal fi al-Baitiwa al-Raudah. Maktabah alSawadi li al-Tauzi, Jeddah.

Raghib Asfahani, H.M. (1992). Mufradat alfaz al-Quran. Damascus, Syria: Dar-ul-Qalam, $1^{\text {st }}$ ed.

Rohana. (2010). What is Education. Nota Kuliah Minggu 1. Skudai: UTM, Not published.

Solehah, Y. \& Rahimah, E. (2008). The Concept of an Integrated Islamic Curriculum and Its Implications for Contemporary Islamic Schools, 13.

Suzalie Mohamad. (2003). Memahami Isu-Isu Pendidikan Islam di Malaysia. Kuala Lumpur: IKIM.

Syed Qutb, I.H. (1992). Tafseer fi zilal al-quran, Dar al-Syuruq-Beirut.

Williams, C. (2007). Research methods. Journal of Business \& Economic Research. Grand Canyon University.

Zainuddin, N, Idrus, R.M \& Jamal, A.F.M. (2016). Integration of Naqli (revealed) Knowledge and Aqli (rational) Knowledge in Postgraduate Courses for Open and Distance Learning. International Journal of Social Science and Humanity, Vol. 6, No. 12, 940. DOI: 10.18178/ijssh.2016.6.12.777

Zetty, N. R. \& Ab.Halim T. (2015). Kepentingan Integrasi IImu Naqli dan IImu Aqli dalam Pengajaran Pendidikan Islam. Jurnal.

http://tamhidi.usim.edu.my/en/program-akademik/senarai-kursus-dan-jam-kredit

http://www.qtafsir.com/index.php?option=com content\&task=view\&id=1109\&ltemid=152 